\title{
Development of the Carpathian Region in the Context of EU Macro-Regional Strategy
}

\author{
Nataliya SYTNYK ${ }^{1}$, Volodymyr HUMENIUK ${ }^{*}{ }^{2}$, Olga SYCH ${ }^{1}$, IrynaYASINOVSKA ${ }^{1}$ \\ *Corresponding author \\ ${ }^{1}$ Ivan Franko National University of Lviv, Faculty of Financial Management and Business, Department of Financial Management, \\ Lviv, UKRAINE \\ ${ }_{2}^{2}$ Ivano-Frankivsk National Technical University of Oil and Gas, Institute of Tourism and Geosciences, Department of Tourism, Ivano- \\ Frankivsk, UKRAINE \\ E-mail: nataliya.sytnyk@lnu.edu.ua, profhumeniuk@gmail.com, olga.sych@lnu.edu.ua, iryna.ysinovska@lnu.edu.ua \\ DOI: 10.24193/JSSP.2020.1.04 \\ https://doi.org/10.24193/JSSP.2020.1.04
}

K e y $\mathbf{w} \mathbf{o} \mathbf{r} \mathbf{d}$ s: Carpathian Euroregion, mountainous areas, regional policy, Macro-Regional Strategy of the European Union, taxonomic index, sustainable development

\begin{abstract}
A B S T R A C T
The article researches the formative process and strategic priorities for the development of the Carpathian Euroregion, and evaluates the economic potential of its regions. A multi-criteria analysis was conducted based on the taxonomic index of development aiming to determine the benchmark values of indexes and detect deviations/delays in territorial development, and observe the ranking of component areas. In the evaluation of the development level, indexes such as population, life expectancy at birth, employment rate, tertiary educational attainment, GDP per inhabitant in PPS, gross domestic expenditure on R\&D, \% of GDP, nights spent in tourist accommodation facilities, passenger cars were assigned to the category of stimulators, whereas unemployment rate, fatal road accidents were defined as destimulators. Thus, we outlined the main problematic development questions for the regions on which the MacroRegional Strategy of the European Union must be focused. The analysis showed the need to implement strategies to create new job opportunities, overcome unemployment, and promote entrepreneurship. Based on studying the successful experience of sectoral support provided by the European Union, the main directions of the European Union policy concerning the development of the Carpathian Euroregion were suggested. The key components of this strategy must include development of civil society, effective communication, activation of modern forms of tourism, creation of new concepts and revival of small towns in the region.
\end{abstract}

\section{INTRODUCTION}

In the case of EU countries, regions are defined as an independent component of the panEuropean programme of spatial development (Council of Europe, 2000). Spatial management devotes much attention to the development of mountainous regions, considering their importance for ecological, economic, tourist and social security.

The Carpathian Euroregion (CE) is a region in Central Europe along the Carpathian Mountains, which unites 19 borderline administrative divisions of five countries, namely, Ukraine: Lviv, Ivano-Frankivsk, Zakarpattia and Chernivtsi regions (oblasts); Poland: Podkarpackie Voivodeship; Slovakia: Košice and Prešov regions; Hungary: Borsod-Abaúj-Zemplén, HajdúBihar, Heves, Jász-Nagykun-Szolnok and SzabolcsSzatmár-Bereg counties; Romania: Bihor, Sălaj, Satu Mare, Maramureş, Harghita, Suceava and Botoşani counties. The Euroregion was established on February $14^{\text {th }} 1993$, in the Hungarian city of Debrecen, where the ministers of foreign affairs signed the agreement. The 
Carpathians, as a unique territory, are less suitable for large settlements, therefore they implicitly belong to less developed regions. Mountainous areas have limited opportunities for agriculture, and the Carpathians have a lower level of accessibility than the Alps. The territory is peripheral, as the main markets and large urbanized centres are located further away. Also, the Carpathian region represents a territory of borders, fact that hinders economic cooperation and integration (UNEP, 2011).

Compared to other analogous structures in the EU, the Carpathian Euroregion does not use the opportunities of cross-border cooperation to accelerate the social and economic development of border territories, increase their competitiveness and improve standards of living for their inhabitants. However, the potential of regional cooperation between Ukraine and the EU is considerable. Little impact has been observed on the activation of cross-border cooperation between Euroregions, for reasons mainly related to the organizational aspect of their formation and development. Euroregions have not yet become the organizationally-financial platform for the coordination of cross-border cooperation.

The problems related to the complete functioning of the cross-border regions at the Western boundary of Ukraine are still unsolved. First of all, these problems include lack of the information on the crossborder activities, development of cross-border markets, and the influence of local communities on cross-border activity etc.

The interregional association "Carpathian Euroregion" was created at the regional level, by the countries that are members of this region. Their activity focuses on:

- assisting the cooperation in various sectors, namely economic, social, scientific, ecological, educational, cultural and sports;

- elaboration and implementation of crossborder projects;

- cooperation with national institutions and organizations.

The "Carpathian Euroregion" shares responsibility for supporting border regimes. Despite the retreat from the limits on cross-border economic transfers and mobility, especially in bilateral relations, the formation of joint space of everyday life de facto remains weakly developed (Tanaka, 2006).

The strategic priorities for the development of the Carpathian region have been determined at the "Framework Convention on Protection and Sustainable Development of the Carpathians" (Kyiv, 2003). It was signed by the Czech Republic, Poland, Romania, Serbia, Slovakia, Hungary and Ukraine. In September 2011, at the "Europe of the Carpathians" conference in KrynicaZdrój, Poland also signed a special memorandum of the Carpathian strategy. The "Carpathian Project" was another initiative that was active in the period of 20052008. It concerned mainly the development of tourism, local trade, nature protection, automobile and railway connections of the Carpathian region, and also small energy projects (Kędzierski, 2012).

Ukraine actively participates in the institutionalization of the region and cooperative projects. During 2008, the activity of the Ukrainian branch in the Carpathian Euroregion was reorganized into the Ukrainian National Council of the Carpathian Euroregion consisting of chair people of the councils of Zakarpattia, Ivano-Frankivsk, Lviv and Chernivtsi regions. Moreover, based on the Association of Local Self-Governments Euroregion Carpathians - Ukraine, another executive structure was established, which is the National Representation of Ukraine in the Carpathian Euroregion, carrying out the following activities:

- coordination of the cross-border activities related to membership in the Carpathian Euroregion;

- assistance in setting up bilateral and multilateral relations;

- participation in conferences and meetings to represent and promote this region;

- participation in project activities - consulting during the elaboration and implementation of the projects.

The strategic aim of the Carpathian Euroregion in general and of its Ukrainian representation in particular is the European Commission's approval of the only operational programme for the Carpathian cross-border region, which also includes financial support. On the $5^{\text {th }}$ of September 2018, within the $28^{\text {th }}$ Economic Forum in Krynica-Zdrój (Poland) the chair people of the Delegations of Ukraine, Poland, Hungary and Slovakia signed the Declaration of Intent on the elaboration of a new Macro-Regional Strategy of the European Union for the development of the Carpathian region (Foundation Institute for Eastern Studies, 2018).

The purpose of this study is to formulate and propose a macro-regional development concept based on the allocation of "growth points" to overcome the inherent "bottlenecks" found in particular areas of Carpathian region.

The new Macro-Regional Strategy of the EU for the Carpathian region has to become the Road Map of assistance in the effective regional development of the Carpathians and the opportunity to complete the mutual tasks for the development of local infrastructure, renewable sources of energy, tourism and recreation; traditional mountainous rural agriculture, forestry, environmental protection, cultural heritage preservation, creation of beneficial conditions for the development of business, clusters and other modern organizational forms of production and agriculture activity. 


\section{THEORY AND METHODOLOGY}

A considerable number of scientific papers have been dedicated to the research of the Carpathian Euroregion, the problems and directions of its future development and functioning. Niewiadomski (2004) has analysed the strengths and weaknesses of the Carpathian region. He states that the Carpathians can be perceived as not an economically advantageous region of the Central Europe, but attractive for its wellpreserved nature, forests and landscape, water resources.

While studying the development questions of the border areas of the region, Tanaka (2006) noted that the Carpathian Euroregion restores regional security by reducing ethnic conflicts and initiating mutual communication on different topics on border territories.

Pryhodko (2018) clarifies the significance of initiation and creation of a constantly working international structure of the Carpathian region of cooperation, consisting of representatives of the governments and cross-border regions of the neighbouring countries and provision of the two-level (national and regional) representation in the governing structures, namely the Council of the Countries of the Carpathian Region of Cooperation and the Council of the Cross-Border Regions of the Carpathian Region.

The analysed works of the authors point to the peculiarities of the region, highlighting its strengths and weaknesses. These studies allow us to select the most important indicators of development of the Carpathian region.

Admitting the importance of the scientific achievements and their significant contribution to the development of the Carpathian Euroregion, it is necessary to deepen the research of problems and outline the directions of the Carpathian region's development in the context of the Macro-Regional Strategy of the EU.

In order to assess the development of individual territories within the Carpathian region based on economic, social and infrastructural indicators, the following methodology is proposed. The method of multicriteria evaluation has become widely used in economics. The main purpose of using the taxonomy method is to construct a generalized estimate of a complex object or process. For the evaluation of the territories in the Carpathian Euroregion, the taxonomic development index should be used. It is a statistical synthetic index, the "resultant" of all characteristics of the units of the researched set, which permits arranging the elements linearly. The process of constructing the taxonomic index of development level starts with the determination of elements of the observation matrix $\mathrm{X}$. As it is known, the elements of this matrix are values of characteristics, expressed in specific measurement units. Therefore, standardization is necessary. The procedure of standardization of characteristics leads not only to the elimination of measurement units but also to the levelling of values.

Consequently, to bring all elements to the form that allows conducting further operations, they must be standardized. The most common method is standardization, where the average value of a characteristic and the standard deviation are used. After the standardization of matrix $\mathrm{X}$, all variables $\mathrm{Z}_{\mathrm{ij}}$ are divided into stimulators and destimulators. The reason for the division of characteristics into two groups is the type of impact each of them would have on the development level of the researched objects. The characteristics that have a positive, stimulative influence on the development level of objects are stimulators, whilst the ones whose impact is negative, are therefore called destimulators.

The following approach is used: we chose the maximal value for stimulators, and the minimal value for destimulators.

The benchmark vector is as follows:

$$
Z_{0}=\left(Z_{01} ; Z_{02} ; \ldots Z_{\text {oj }}\right)
$$

The distance between the elements of the matrix and the benchmark vector can be defined by the formula:

$$
C_{i o}=\sqrt{\sum_{j=1}^{m}\left(Z_{i j}-Z_{o j}\right)^{2}}
$$

where: the region $i$.

$\mathrm{Z}_{\mathrm{i}} \mathrm{j}$ is the standardized value of the index $\mathrm{j}$ in

To calculate the development level, the index $\mathrm{d}$ is used, which is obtained by conducting the following calculations including the average distance to the benchmark and the standard deviation:

$$
D_{i}=\frac{C_{i o}}{C_{o}}
$$

The total distance between indexes and the benchmark:

$$
C_{o}=\overline{C_{o}}+2 S_{o}
$$

where:

$\overline{C_{o}}$ - the average distance between indexes and the benchmark;

$S_{o}$ - the standard deviation. 
The average distance:

$$
\overline{C_{o}}=\frac{1}{m} \times \sum_{i=1}^{m} C_{i o}
$$

The standard deviation:

$$
S_{o}=\sqrt{\frac{1}{m}} \times \sum_{i=1}^{m}\left(C_{i o}-\overline{C_{o}}\right)^{2}
$$

The index of the development level $d_{i}$ is a positive value in the range from zero to one, characterized by the fact that it has positive magnitude and can be more than one only with probability close to zero. The closer to zero the value of development index is, the higher development level the given unit has.

Accordingly, multicriteria analysis will allow for the ranking of territories by their development level, while pointing to factors that bring them closer or distance them from the standard.

\section{RESULTS AND DISCUSSION}

From our perspective, to find a solution to the problems of the region and the development of its potential, a strategic view on the cooperation of partner countries must be created. Based on the multi-year successful experience of creating macro-regional strategies by the EU (The EU Strategies for the Baltic Sea Region (2009), the Danube Region (2010), the Adriatic and Ionian Region (2014), the Alpine Region (2015)), we considered appropriate to formulate and implement a corresponding strategy for the Carpathian region. Its aim would be to assist the effective territorial development of the Carpathian territories and level the colossal disparities in regional development. The priorities defined by the Strategy permit conducting joint projects for solving development issues of the Carpathians as follows:

- strengthen economic cooperation;

- advance environmental quality;

- increase functional accessibility within the Carpathians;

- establish institutional cooperation.

\subsection{Comparative features of the main development indicators of the Carpathian Euroregion Countries}

The Carpathian Euroregion covers 145,000 km² (Carpathian Euroregion, 2015). The territorial units belonging to the partner countries are shown in Fig. 1.

The difference in population density and structure of settlements demonstrates different characters of regions. For instance, despite the existence of larger city centres, several Hungarian counties are characterized by a high number of villages; these rural regions usually encounter hard economic and social problems (e.g. poverty, emigration, drawbacks in the service sector), but they can also have natural values and traditional way of life, and their attractiveness may be used as a basis for green farming and ecotourism. Other regions, namely the mountainous areas of Poland, Lviv region of Ukraine, Košice region of Slovakia, are more densely populated. Some urban territories are represented by small towns with limited opportunities of water supply or competitiveness.

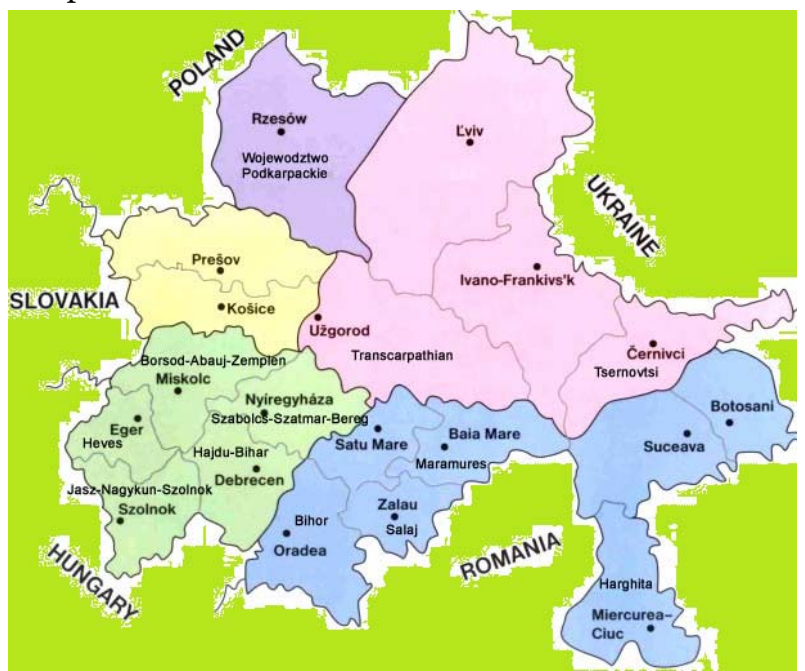

Fig. 1. Territory of the partner countries of the Carpathian Euroregion. Source: Carpathian Euroregion, 2015.

The peculiarity of many cities in this region is the post-industrial history of mining activities. Such monofunctional towns need revitalization (Sych and Pasynovych, 2015). Society ageing and emigration are the most important demographic problems in rural areas: the tendency of ageing gets worse every year, but Hungary feels it the most. The considerable decrease in population reduces the amount of workforce in the region, which threatens competitiveness. Some parts of the Carpathian Euroregion encounter serious social challenges, which appear because of the presence of mostly uneducated, unemployed and poverty-affected Roma.

The educational level of population is a significant factor for the labour market. From this point of view, the Carpathian Euroregion lags behind the average level of the EU (although there are some positive tendencies): the share of people with low level of education is high, whereas the number of inhabitants with a higher education level can be considered low (except of large cities). The main reasons are the selective emigration and the fact that the amount of money spent by the state on education is much lower than the average amount spent in the EU. The educational systems of partner countries have 
considerable differences, which complicates the crossborder cooperation. The same can be said about medical and social help: the cross-border migration of patients is almost absent, while harmonization of legal and strategic documents may have a positive impact on the mutual usage of services by inhabitants. Healthcare is one of the important factors of life expectancy at birth: on the one hand, life span has been increasing for five years in the whole Euroregion; on the other hand, there are significant interregional differences. Population health status partially depends on the quality of infrastructure and services in the healthcare sphere; there is a major need in their development (especially for people in a disadvantageous condition).

The differences in the development level and internal opportunities are also displayed in the key economic areas. Some examples:

- in mountainous areas, wood-processing and mining industries are important, whilst lowlands provide optimal conditions for vegetable crops or fruitgrowing;

- the more developed urban areas benefit from knowledge-based industries (for example, aircraft and machine, chemical and pharmaceutical, automotive industries, IT services);

- in less developed and rural regions labourintensive activities dominate (for example, agriculture, food and light industries).

These facts, particularly the wide spectre of activities, may lead to different benefits:

- it can be a basis for horizontal and vertical economic integration and cooperation, clusters (e.g. sustainable tourism, agroindustrial products, renewable energy);

- it creates opportunities for interregional trade;

- the above-mentioned diversity may ensure a certain security from economic crises and instability.

In the Carpathian Euroregion there are about 300,000 enterprises, most of which are located in Hungary, as evidenced by the data about business density.

However, most of them are small and medium-sized enterprises with weak innovative potential and limited financial resources. More multinational corporations choose cities of the Carpathian Euroregion as a place for their industrial facilities (for example, US Steel and Whirlpool in Slovakia, Michelin and Bosch in Hungary, Electrolux in Romania, Asseco and Sanofi-Aventis in Poland), although business infrastructure may be considered high-quality only in large cities. Some industrial parks and incubators for small and medium-sized enterprises are characterized by a low coefficient of usage. The main reasons for this are the insufficient infrastructure, disadvantageous location, drawbacks of the labour market, low level or even lack of business services. Really successful industrial facilities (enterprises), the ones which have the highest employment rate, are located in large cities (more exactly, in the central cities of regions).data on the values of the main relevant indexes registered in components of the region are shown in Table 1.

Table 1. The main regional development indexes for the states within the Carpathian Euroregion. Source: Eurostat (2019); European Union (2019).

\begin{tabular}{|l|rrrrr|}
\multicolumn{1}{c|}{ Indexes } & Romania & Hungary & Ukraine & Slovakia & Poland \\
\hline Population, 2018 thousand inhabitants & 2560,8 & 2594.9 & 6131.9 & 1623.0 & 2085.8 \\
Life expectancy at birth, 2016 years & 75.3 & 75.1 & 72.88 & 77.2 & 79.2 \\
Employment rate (ages of 20-64), 2017 & 71.5 & 69.8 & 55.0 & 66.1 & 68.2 \\
Unemployment rate (15 years or over), 2017 & 3.6 & 6.6 & 8.7 & 12.0 & 8.4 \\
Tertiary educational attainment (ages of 30-34), 2017 & 26.5 & 25.6 & 63.0 & 29.0 & 41.6 \\
GDP per inhabitant in PPS (\% of EU-28 avg.), 2017 & 56.0 & 44.5 & $29.0 *$ & 54.0 & 49.0 \\
Gross domestic expenditure on R\&D, 2015\% of GDP & 0.41 & 1.58 & 0.45 & 0.75 & 1.0 \\
Nights spent in tourist accommodation, 2017 & 551,328 & $1,169,690$ & 561 & $1,059,503$ & 303,657 \\
Passenger cars, 2016, per 1 000 inhabitants & 279 & 288 & 202 & 317 & 517 \\
Fatal road accidents, 2016 per 1 million inhabitants & 91 & 57 & 500 & 40 & 100
\end{tabular}

Data in the table provides an overall assessment of the Carpathian region. There are 5 domains statistically assessed - economics, education, labour market, tourism and transport. This classification is used by the EU in creating the euromaps of regions.

Besides, such cities are centres of research, technologic development and innovation. Despite the remoteness from the national capitals, $\mathrm{CE}$ regions have a saturated academic life. There is a high number of universities, institutes and faculties that provide training for more than 200,000 students.

The universities and research institutes in the region provide a high-level academic education and have a considerable potential for scientific research. The indexes of labour market in the Carpathian 
Euroregion are significantly lagging behind the European average value. There are certain differences between member countries, urban and rural areas. The cross-border mobility of workforce is not essential mainly because of the absence of cross-border management of the labour market, language barriers and partially inadequate transport infrastructure. The absence of mutual recognition of diplomas hinders the activation of the dynamic cross-border labour market and other kinds of cooperation.

The problems of transport infrastructure and services can influence each kind of cross-border cooperation, in terms of intensity and regularity. Despite the large-scale development projects of the last decade, several serious issues have remained unsolved:

- absence of appropriate north-south transport connections;

- insufficient density of roads and highways;

- low quality or absence of smaller roads to ensure connection with the border across it;

- infrastructure disparities concerning the railway network;

- permeability of borders;

- uncoordinated and unharmonized services of the cross-border public transport.

External transport communications also play an important role in tourism development, which has been defined as one of the priorities of the EU MacroRegional Strategy.

Numerous cultural and natural tourist attractions create a strong basis for mutual efforts to increase the attractiveness of this territory:

- UNESCO world heritage sites (villages with wooden churches in Poland, old city of Lviv in Ukraine);

- natural treasures, namely 26 national parks, other protected areas, mountains, caves, forests, lakes and rivers;

- winery regions and routes (Romanian vineyards);

- museums, architectural monuments (churches and cathedrals, castles, palaces, ruins), although affected by continuous degradation;

- thermal water resorts (Heviz, Zalakarosh, Hajdúszoboszló in Hungary);

- folk art and traditions;

- tourist events and festivals.

Therefore, the Carpathian Euroregion has a significant potential for recreational activities and development of different types of tourism, particularly balneological and recreational tourism; cultural, architectural and religious tourism; rural tourism; gastronomic tourism, active tourism (rafting, skiing, cycling); business tourism.

Tourist resorts and recreational sites have been developed in the Carpathian region most intensively. Tourism has preoved to be a complex, investment-attracting and highly profitable economic activity, which may determine a multiplicative effect. On the one hand, there are the incomes of producers of resorts and recreational services, new workplaces, financial flows of salary, social transfers, taxes, rent; and on the other hand, there are investments in human capital.

The resulted multiplier effect is influenced by natural and geographical, historical and cultural, social and economic factors of differentiation of the resorts and recreational potential, which further trigger heterogeneity and unevenness in management at the level of administrative divisions. However, despite the considerable potential, the Carpathian Euroregion faces serious problems regarding the quality and scale of development of tourist infrastructure and services, and also drawbacks in the effectiveness and organization of the cross-border tourism marketing (Humeniuk, 2018).

The territory of the Carpathian Euroregion is very sensitive to the impact of climate change: most parts of the CE can expect a significant increase in the average summer temperature and decrease in winter. These changes may cause different challenges (for instance, floods, heat waves, droughts), which can be processed more effectively with a cross-border management of risks. Climate changes influence biodiversity, conditions of protection of nature, particularly forests.

The use of renewable energy sources is one of the ways of alleviating the effects of climate change. The Carpathian Euroregion has a considerable potential for geothermal, solar and wind power, bioenergy and hydropower, but the quotient of renewable energy sources in the gross final usage of energy is very low (except of Romania).

Migration and cross-border mobility are the decisive factors in the context of cross-border cooperation. In some border regions (especially between Romania and Ukraine) the number and density of border crossing points is very low in comparison with the border length. There is no data about the number of passengers and means of transportation that cross the border between Schengen Countries. The number of people who legally cross the border from Ukraine or into Ukraine has decreased, especially because of the crisis in Ukraine.

Regarding the procedure of crossing the boundary, some problems appear, namely:

- the inefficient, opaque and labour-intensive process;

- the absence of harmonized procedures at the border and customs;

- drawbacks of border crossing management, including staff problems and corruption;

- drawbacks in technical infrastructure, even after certain modernization of border crossing points;

- absence of border crossing points for pedestrians and cyclists. 
Illegal migration is one of the key questions in the EU. The increasing pressure from the side of illegal migration is caused by geopolitical risks, which determine international conflicts. Illegal migrants use the countries of the Carpathian Euroregion mostly as transit zones. The European Union is interested in controlled migration to its territory, preventing illegal migration to neighbouring countries.

Despite the differences between countries and physical borders and language barriers, there are many good examples of cross-border cooperation in different fields (for instance, tourism, education, protection of nature etc.), partially due to the programs funded by the European Union. But these types of cooperation are enhanced mainly by external resources. The differences between the systems of state governance and legal framework also complicate the regular and permanent cooperation.

\subsection{Detection of opportunities and threats of the development}

For the evaluation of tendencies and their impact on the economic growth, a set of calculations was done. To compare units of the statistical data (in this case, five regions of the countries of Slovakia, Hungary, Romania, Poland and Ukraine, based on the data in Table 1) and their arrangement, the taxonomic index of development level was used. This is a synthetic index, which results from the combination of the values of all characteristics considered. The taxonomic index of development level of a region's component defines its relative position in the group is calculated by the distance to the chosen basis of comparison (benchmark point). The lower the value of the taxonomic index of development is, the closer it is to the benchmark. In the evaluation of development level, it has been defined that indexes such as population (thousand inhabitants), life expectancy at birth (years), employment rate (ages of 20-64), tertiary educational attainment (ages of 3034), GDP per inhabitant in PPS (\% of EU-28 average), gross domestic expenditure on R\&D, \% of GDP, nights spent in tourist accommodation facilities, passenger cars belong to the category of stimulators, whereas unemployment rate (15 years or over), fatal road accidents belong to the category of destimulators. For our analysis, we chose the indexes of Eurostat. The distribution of indicators into groups of stimulators / destimulators was based on the expert judgment of the authors of the article.

The average values and standard deviations were calculated for each index, whereupon the matrix of the standardized values was achieved (Table 2).

The coordinates of the benchmark point $\mathrm{Z}$ have been defined:

$Z=(1.74 ; 1.37 ; 0.83 ;-1.38 ; 1.63 ; 0.88 ; 1.58 ; 1.19 ; 1.66 ;-$ $0.609)$

The distance from each unit of observation to the benchmark point was calculated, and the taxonomic index of development was defined. The corresponding calculations allowed us to draw the following conclusions.

Table 2. Evaluation of the taxonomic development index of the Carpathian Euroregion

\begin{tabular}{|c|c|c|c|c|c|c|c|}
\hline \multirow{2}{*}{ Indexes } & \multirow{2}{*}{$\begin{array}{l}\text { Average } \\
\text { value }\end{array}$} & \multirow{2}{*}{$\begin{array}{l}\text { Standard } \\
\text { deviation }\end{array}$} & \multicolumn{5}{|c|}{ Standardized value } \\
\hline & & & Poland & Ukraine & Romania & Hungary & Slovakia \\
\hline Population, thousand inhabitants & $2,999.28$ & $1,795.66$ & -0.50 & 1.74 & -0.24 & -0.22 & -0.76 \\
\hline Life expectancy at birth, years & 75.93 & 2.38 & 1.37 & -1.28 & -0.26 & -0.35 & 0.53 \\
\hline Employment rate (ages of 20-64) & 66.2 & 6.35 & 0.31 & -1.69 & 0.83 & 0.56 & -0.01 \\
\hline Unemployment rate (15 years or over) & 7.86 & 3.07 & 0.17 & 0.28 & -1.38 & -0.41 & 1.34 \\
\hline Tertiary educational attainment (ages of 30-34) & 37.14 & 15.82 & 0.28 & 1.63 & -0.67 & -0.72 & -0.51 \\
\hline GDP per inhabitant in PPS (\% of EU-28 avg.) & 46.5 & 10.75 & 0.23 & -1.62 & 0.88 & -0.18 & 0.69 \\
\hline Gross domestic expenditure on R\&D, \% of GDP & 0.83 & 0.47 & 0.33 & -0.80 & -0.89 & 1.54 & -0.18 \\
\hline Nights spent in tourist accommodation & 729,082 & $368,805.5$ & -1.15 & -0.45 & -0.48 & 1.19 & 0.89 \\
\hline Passenger cars, per 1000 inhabitants & 320.6 & 117.73 & 1.66 & -1.00 & -0.35 & -0.27 & -0.03 \\
\hline Fatal road accidents & 157.6 & 192.96 & -0.29 & 1.77 & -0.34 & -0.52 & -0.60 \\
\hline Distance to the benchmark & 5.01 & 0.98 & 4.13 & 6.60 & 4.99 & 4.27 & 5.0 \\
\hline Taxonomic index of development & - & - & $\begin{array}{r}0.59 \\
(1)\end{array}$ & $\begin{array}{r}0.94 \\
(5)\end{array}$ & $\begin{array}{r}0.71 \\
(3)\end{array}$ & $\begin{array}{r}0.61 \\
(2)\end{array}$ & $\begin{array}{r}0.72 \\
(4)\end{array}$ \\
\hline
\end{tabular}

Regions are at different stages of development, although with time the differences do not decrease, but grow. The gross regional product is smaller than the average in the country and is less than half of the European average. The unemployment rate remains high. After the evaluation, we concluded that the
Carpathian regions of Poland are the closest ones to the benchmark values (due to long lifespan, number of cars per inhabitant), followed by the regions of Hungary (because of lower unemployment rate, intensive development of tourism, investments in scientific and technical progress). The regions of Slovakia and 
Romania are almost at the same level, and the mountainous areas of Ukraine have the lowest predicted indexes of development.

The conducted analysis outlined important clusters of problems, which the future strategy must be focused on: firstly, human capital; secondly, provision of sustainable development based on the ecologic and economic approach; thirdly, creation of an active platform for cooperation, search for creative decisions and implementation of innovation in the region.

\subsection{Experience of the $E U$ in elaboration of the policy for mountainous areas}

Despite the lack of a holistic integrated and formalized European strategy concerning mountainous territories (i.e. within the cohesion policy), the legal and regulatory basis of the EU recognizes mountainous territories as such, this fact requiring certain individual attention and support in view of the relatively low level of availability and permanent natural and demographic limits, which mainly concern agriculture.

The spatial management of mountainous regions is oriented towards saving ecosystems and effectively use natural resources, increase competitiveness of agriculture and forestry, diversify economic activities, create conditions for the economic and social revival of rural regions.

The mountainous policy has been an important component in the national and regional regulations of the European countries since the 1960s, as an instrument for finding solutions to social and economic problems of population in mountainous territories, realization of national and global ecological programs of such territories, conservation of unique ethnic and cultural heritage of local communities. This policy has developed differently in the member countries, in some cases, once with the creation of the European Union, states unifying around mutual principles.

The significance and value of mountain ecosystem started being recognized in the middle of the $19^{\text {th }}$ century, when several countries of the Alpine region (starting with Bavaria and Austria in 1852) adopted the laws on regulation and limiting deforestation. At the beginning of the $20^{\text {th }}$ century, the aesthetic and biodiverse values of mountains were acknowledged by creating national parks, firstly in Sweden (since 1909), in 1910 s in Spain and Switzerland, in 1920s in Italy, and in 1930s in Bulgaria, Greece, Poland and Romania (Council of Europe, 2000).

Although the specificity of mountainous areas was taken into account, that recognition did not determine the appearance of a certain public policy, which was elaborated only at the beginning of the $20^{\text {th }}$ century. At first, the public policy of different countries, later members of the $\mathrm{EU}$, foresaw measures for beneficiaries in mountainous areas, mainly subsidies for farmers. Such countries as Italy, Switzerland and France adopted laws on assistance in the socioeconomic development and protection of nature in these areas.

The support mechanisms in most countries of the EU include: business consultancy; online manuals and case studies; trainings, seminars, state-funded conferences and other events (for example, in Spain, Germany and other countries that are members of the EU); information about getting access to finances, including subsidies and loans of local authorities; individual consulting support (the system of business angels); help for enterprises to set up international trade (for instance, such a mechanism of support works in France); advice on hire and preparation of staff for stimulation of employment and provision of conformity of the skills of workforce to the market's requirements; support of participation in the processes of state purchases by implementation of a set of instruments of electronic commerce (available in England and Wales).

Setting up special schemes for supporting young entrepreneurs is of great importance, as they require more intensive and longer financial provision. In the EU, a significant role is played by the programme "Horizon 2020" for research and innovation, which is funding projects for better ideas and discoveries to be able to reach the market quickly, to enable their results to assist the social and economic growth in Europe (European Commission, 2019). Member states do not use only this programme, but also other parallel forms of support, using the programme "Horizon 2020" and their own funds: creation of pools of direct financial resources for support of innovators at the early stages of the project - this help is provided for all entrepreneurs at the early stages of development of production and experimental manufacturing, which is hard to get access to from traditional funding sources; creation of funding mechanisms aimed at the support of innovative projects, which are conducted by universities and business in partnership.

\subsection{Variants of key strategies for the Carpathian Euroregion}

It is worth sorting all the programs and ideas for the development of the region according to the results of the analysis. Firstly, we describe the measures that will reduce the gap against the standard; secondly, we eliminate "bottlenecks" and, finally, we underline those ideas that will contribute to capacity building and will stimulate "growth points". The analysis showed the need to implement strategies to create new job opportunities, overcome unemployment, and promote entrepreneurship.

Undoubtedly, the development potential of the Eastern Carpathians and the benefits of its joint usage 
are the common denominator for all member countries of the Carpathian Euroregion and, accordingly, the reason for planning future measures. Based on this potential, in order to assist and coordinate the socioeconomic development of the territories several steps should be taken, based on:

1). Professional juridical structures of cooperation, which will allow for the coordination of activity at international level, with simultaneous adjustment of interests of local governments, entrepreneurs and non-governmental organizations.

2). Common development strategy; such a strategy, along with regional strategies, should be the reason for authorities of member countries and regions to coordinate and synchronize supra-regional policies of development and investments.

3). Use of opportunities of assistance in territorial cooperation and regional development within the framework of the EU operational programmes. This also implies training and specialization of the structures responsible with the implementation of these measures, and the increase of beneficiaries' ability to make use of the benefits provided. Besides, it is highly important to improve assistance mechanism to coordinate joint projects.

The mountainous area brings out obvious challenges, but also provides opportunities for development. Mountainous regions are quite diverse, fact that complicates the implementation of the integrated European strategy. However, development strategies of mountainous areas can be elaborated by considering the specific problems and significance of mountainous agriculture, the high level of biodiversity and its specific impact on climate change. The cohesion policy could use such an association of regions to solve more effectively demographic problems in many mountainous regions and achieve a more efficient socioeconomic development.

The preconditions for further development are: economy, accessibility, transport and provision of services. Insufficient economic diversification causes fragile labour markets, which cannot provide opportunities for local youth, thus leading to depopulation, reduction of stability, and external negative economic impacts. Mountainous areas have old traditions of diversification, and it is possible to find many interesting practices, which are worth to be shared. Economic diversification can be supported by remote employment through modern information technology.

Strategies aiming to make use of remote employment as a development factor must consider modern tendencies and differences between European countries. The implementation of digital technology creates many advantages, including the opportunity of direct interaction with clients, development of new processes and products, selling products on the world market 24 hours a day for a comparatively low price. Broadband internet can be developed through the mechanism of state and private partnership. Extended broadband access will support economic development, improve education level and management. Accordingly, assistance in the development of digital technology is particularly important.

The support policy for mountainous areas must be aimed not only at reaching economic results in separate projects, but also to contribute to a balanced development of communities and regions. In this regard, the concept of "public good" has a significant meaning. To enhance the role of structural funds in supporting the development of mountainous areas, individual initiatives must realize their social, ecological and economic costs and benefits. To enhance accessibility, much attention should be paid to the "solid infrastructure". Structural funds are designated to support the implementation of projects of business, entrepreneurship and innovations.

The problems connected with the provision of services in remote mountainous areas are very similar to problems found on small islands and in sparsely populated territories. The profitability in such regions is often too low for private business to provide services of common usage quickly, and the cost of their provision is high because of the absence of a proper economic scale. The strategic options to solve these deficiencies must stimulate alternative and innovative solutions. It is necessary to work out individual decisions, which could be adapted to local and regional needs and opportunities.

The main objectives of the projects aiming to solve ecological problems, which are being implemented in the Carpathian Euroregion, are the following:

- save the unique ecosystem of the Carpathian Euroregion and its natural and historical complex;

- reach the maximal possible economic effectiveness, with minimal impact on the environment;

- carry out research studies tackling the problems of land resources use maintaining stability and saving the ecosystem of the Carpathian Euroregion;

- provide opportunity for the main state members to get acquainted with and participate in joint works, especially during the foreign business trips and exploring the activities of the organizations in the sphere of state management of natural resources and environmental quality;

- create/ define perspectives for the sustainable management of forest cover and wood processing; and consider reasons and principles of business while organizing ecotourism.

Programmes supported by structural funds will not be able to solve all the different problems of the mountainous regions, especially after 2020. The aim should be to create a framework that will help regional 
and national programmes to use opportunities, solve development problems in mountainous territories and encourage the cooperation between the programmes that are available in separate domains.

To find a solution to the demographic, economic and ecological problems in mountainous areas, integrated approaches and usage of structures for coordination of intersectoral policy are needed. The cohesive policy can increase effectiveness by mainly considering the specificity of mountainous regions.

Any government, be it national or regional, aiming to stimulate economic growth in order to reach economic and social goals, comes to the question: how to stimulate particular members of the market to act as to achieve the results proposed in the national or regional development plans? Although all projects have their individual specificity, each of them usually requires certain support.

It is necessary to consider the sectoral aspects, especially when countries define the priority of high technology and innovations that bring higher added value in the development of manufacturers, and also the aspects of regional development, in case a certain region needs targeted support, for example, in the development of tourism and agriculture. However, support is general and can be used (with certain modifications) in all sectors and regions.

The framework of the "horizontal policy" determines stimulation of innovations and entrepreneurship not only as a process of business development, but also as a process connected to education and the idea of creating a new generation of entrepreneurs.

For this, a set of educational means is required: assistance in the development of enterprises and stimulation of employment in the regions; financing the development of new technology and materials; financing a wide spectrum of research projects: from increasing the quality of transport, food, healthcare system and safety to the individualization of European identity and cultural heritage; financing highquality individual and team research projects in all spheres of knowledge etc.

In many countries there is no single general mechanism for investing in innovations. There are cases in which several state programmes and concepts were adopted but did not result in active implementation of innovative works in the manufacturing process of enterprises. The reason that deters private investors from investing all their capital in innovations is often the absence of legal guarantees of returning own savings (Yasinovska and Smolinska, 2018).

For keeping the investment component of financial security at the proper level it is necessary to: create proper financial conditions to ensure the regular investment of innovative projects; diversify the structure of the economy; ensure functioning of mechanisms of protection of rights of local and foreign investors (Sytnyk and Gerasymenko, 2018).

The conducted research on the Ukrainian resorts point out that the financial security of enterprises with foreign investments from the EU countries is better than that of the ones based on national funds, and the development of resorts and recreational tourism maintaining financial security, looks less problematic in the Carpathian region of Ukraine since 2014, particularly in Zakarpattia, IvanoFrankivsk and Lviv regions, which neighbour the EU countries. It is mainly the case of resorts that have already gained international tourist recognition (Truskavets, Morshyn, Bukovel) (Humeniuk, 2019).

In our opinion, the most suitable is the systemic approach to the analysis of architectonics of an enterprise's economic security, which, except of the social component, includes the social, intellectual, investment, technical and technological, informational, marketing components.

The European Institute of Innovations and Technology favours European competitiveness, sustainable economic growth and creation of workplaces by encouraging and strengthening the synergy and cooperation between enterprises, educational institutions and scientific organizations. Their main objectives are: to encourage teachers to develop entrepreneurial thinking of pupils (students learn planning business and, in fact, create test products or services); to create special support schemes for young entrepreneurs; to create pools of direct financial resources for support of innovators etc.

Entrepreneurial initiatives may be successful in territories where special concentration of market requirements exists. At the same time, the improper level of life quality of inhabitants is often the main problem of the mountainous areas usually because of remoteness. But these features are not enough: entrepreneurial structures will be able to develop where there is some potential for economic growth.

One of the most important objectives of the business sector in the Carpathian region is the organization of civil society who must develop creative and innovative partnerships with business entities (Csáfor, 2006). National and regional authorities are interested in supporting social enterprises: they may be used to support social programmes or can be selfsufficient businesses.

In order to achieve higher parameters of sustainable development and quality of life in the European Union, as well as for Ukraine and the countries of Central Europe, which are its neighbours in the Carpathian region, political, social and economic decisions are needed:

1). Initiate and create a constantly working international structure of cooperation of the Carpathian region (CCR) consisting of representatives of the 
governments and cross-border regions of the neighbouring countries;

2). Provide a two-level (national and regional) representation in such governing structures of the CCR such as the Cooperation Council of the Countries of the Carpathian Region and the Cooperation Council of the Cross-Border Regions of the Carpathian Region at the level of ministers of foreign affairs and governors of cross-border regions;

3). Regarding the European identity of potential members (countries and regions), consider adding new governing bodies, as a third, nongovernmental house, namely the Cooperation Council of the Society of the Carpathian Region (Public Council), consisting of representatives of ethnic, gender, confessional and other communities of the Carpathian region;

4). Rotating chairmanship of councils of representatives of countries, regions and society and approve decisions by consensus;

5). Elaborate the project of the Carpathian Centre for Cross-Border Cooperation for the Management and Training of Personnel in order to reorient their activities towards European forms, methods and technology of public and business administration (Prykhodko, 2018).

After the European integration and its strong regional impact on the "internal" and "external" borders, the western regions of Ukraine have considerably and qualitatively changed their status having opportunities to gain increased funding from the EU. The actual question of the modern Euroregional cooperation is the qualitative improvement of functioning of Euroregions in terms of European integration. Besides, the optimization of the priority of cross-border cooperation in terms of the closest neighbouring areas of the European Union and Ukraine is highly relevant. This is important for Ukraine, as it is the only member country of the first international association (the Carpathian Euroregion) which is not a member of the EU. Therefore, the European integration is especially significant for the external policy of Ukraine at the regional level (Kovach, 2015).

The support of mountainous territories may include: the administrative policy, which will provide special status to administrative divisions and settlements in mountainous areas with particular approaches for financial equalization, investment activity etc.; territorial planning and setting up administrative divisions, considering the mountainous specificity; financial and budget equalization, to provide proper living conditions for the local communities in economically problematic territories in mountainous regions; target assistance programmes for the development of activities considered especially significant for mountainous areas; creation of infrastructural programmes to diminish deficiencies of transport and communicative accessibility in mountainous areas.

\section{CONCLUSIONS}

The components of the Carpathian Euroregion are at different development stages, although with time, differences between them do not decrease, but grow. The gross regional product is smaller than the average of the country and is less than a half of the European average. The unemployment rate remains high. The evaluation results show that the Carpathian regions of Poland are the closest ones to the benchmark values (at the expense of long lifespan, number of cars per inhabitant), followed by the regions of Hungary (on account of lower unemployment rate, intensive development of tourism, investments in scientific and technical progress). The regions of Slovakia and Romania are almost at the same level, and the mountainous areas of Ukraine have the lowest predicted indexes of development.

The use of the taxonomic development index allows using the multicriteria evaluation and defining the rating of regions in comparison with their neighbours.

The conducted analysis outlined important clusters of problems, which the future strategy must be focused on: firstly, human capital; secondly, provision of sustainable development based on ecologic and economic approach; thirdly, creation of an active platform for cooperation, search for creative decisions and implementation of innovation in the region.

Therefore, directions of further assistance and coordination of the socioeconomic development of the Carpathian Euroregion are worth to be developed considering its potential.

The coordination of activity at international level with harmonization of interests of local authorities, business and non-governmental organizations is possible to be assured by professional cooperation structures.

A highly actual question is the elaboration of the common development strategy, which, together with regional strategies, would become the foundation for the coordination and synchronization of development policies and investments at supra-regional level, bringing together separate countries and regions.

The key components of this strategy must be the following:

- development of civil society and effective work of institutions in support of local initiatives and business;

- communication and connection for the creation of remote workplaces and exchange of information, ideas, experience, initiatives;

- activation of modern forms of tourism and active rest, support of creative economy in the region; 
- protection and restoration of biodiversity in the Carpathians, nature management in the context of sustainable development;

- creation of new concepts and revival of small towns in the region.

It is important to set up an effective mechanism for the combination of separate instruments and projects to assist in joint events, and territorial cooperation and regional development, including the already working programmes of the EU.

\section{REFERENCES}

*** (2013), Karpatskyi Evrorehion: regional platforma intehratsii Ukraina-ES (Carpathian Euroregion: Regional platform for Ukraine-EU integration). Mountain School of the Ukrainian Carpathians, 8-9, 10. URL: http://irbis-nbuv.gov.ua/cgi-bin/opac/search.exe ?I21DBN=LINK\&P21DBN=UJRN\&Z21ID $=\& S 21 R E F=1$ $0 \& S 21 \mathrm{CNR}=20 \& \mathrm{~S} 21 \mathrm{STN}=1 \& \mathrm{~S} 21 \mathrm{FMT}=\mathrm{ASP} \_$meta\&C21 $\mathrm{COM}=\mathrm{S} \& 2 \_S 21 \mathrm{Po} 3=\mathrm{FILA}=$ \&2_S21STR=gsuk\%5F2O13 \%5F8\%2D9\%5F5. Accessed on September 5, 2019

Regional Development Association for the Carpathian Euroregion (2015), The Carpathian Euroregion strategy 2020 and beyond. URL: http://carpathianeuroregion.org/letolt/strategiaenglish. pdf. Accessed on September, 17, 2019.

Council of Europe (2000), Guiding principles for the sustainable spatial development of the European continent. European Conference of Ministers responsible for Regional Planning (CEMAT). URL: https://rm.coe.int/1680700173. Accessed on September 17, 2019.

Csáfor H. (2006), Corporate social responsibility in the countries of the Carpathian Euroregion. Periodica Polytechnica Social and Management Sciences, 14(2), 45-52. DOI: https://doi.org/10.3311/pp.so.2006-2.01. Accessed on September, 5, 2019.

European Commission (2019), Horizon 2020: Overview of funding programmes. Available at: https://ec.europa.eu/info/funding-tenders/fundingopportunities/funding-programmes/overview-fundingprogrammes_en. Accessed on September, 17, 2019.

European Union (2019), Regional Policy. URL: https://europa.eu/european-union/topics/regionalpolicy_en. Accessed on September, 17, 2019.

Eurostat (2019), Regions and cities - Overview. URL: https://ec.europa.eu/eurostat/web/regions-and-cities. Accessed on September, 17, 2019.

Foundation Institute for Eastern Studies (2018). The $28^{\text {th }}$ Economic Forum Krynica-Zdroj, Poland, 4-6. Materials of Foundation Institute for Eastern Studies. URL: http://www.forum-ekonomiczne.pl/28theconomic- forum-2018-description/?lang=en. Accessed on September, 5, 2019.

Humeniuk V. (2019), Financial security of enterprises in resort and recreation sphere. Financial and Credit
Activity: Problems of Theory and Practice, 1(28), 87-94. DOI: https://doi.org/10.18371/fcaptp.v1i28.164013. Accessed on September, 10, 2019.

Humeniuk V. (2018), Financial nature of resort multiplier. Financial and Credit Activity: Problems of Theory and Practice, 2(25), 417-423. DOI: https://doi.org/10.18371/fcaptp.v2i25.136501. Accessed on September, 10, 2019.

Kęndzierski M. (2012), Strategia karpacka szansa na nową konsolidację regionu? (Carpathian strategy - a chance for a new consolidation of the region?) [article in Polish], Nowa Europa Wschodnia. URL: http://www.new.org.pl/959-strategia-karpackaszansa-na-nowa-konsolidacje-regionu. Accessed on September, 5, 2019.

Kovach V. (2015), Carpathian Euroregion as an example of euroregional cross-boundary cooperation. Economy of Agro-Industrial Complex: International Scientific and Production Journal, 11, 96-101. URL: http://eapk.org.ua/en/contents/2015/11/96. Accessed on September, 17, 2019.

Niewiadomski Z. (2004), The Carpathians as a region of international co-operation. Europa Regional, 12(4), 168-172. URL: https://www.ssoar.info/ssoar/ bitstream/handle/document/48129/ssoar-europareg2004-4-niewiadomski-The_Carpathians_as_a_region. pdf? sequence $=1$ \&isAllowed $=y \& \ln k$ name $=$ ssoareuropareg-2004-4-niewiadomski-The_Carpathians_as _a_region.pdf. Accessed on September 10, 2019.

Prykhodko V. (2018), North-European experience as an actual model of cross-border cooperation between Ukraine, Hungary and other EU countries: Visegrad Group in the Carpathian region. Strategic Priorities, 1(46), 70-78. URL: https://niss-priority.com/index. $\mathrm{php} /$ journal/article/view/22/21. Accessed on September, 17, 2019.

Sych O., Pasinovych I. (2015), Consolidation of financial resources for postindustrial cities revitalization. Economic Annals XXI, 9-10, 87-90. URL: http://soskin.info/userfiles/file/2015/9-10_2015/

Sych_Pasinovych.pdf. Accessed on September 5, 2019.

Sytnyk N., Gerasymenko O. (2018), Influence of investment policy on financial safety of the state in context of balancing. In: Improvement of Investment Activity of Enterprises: Challenges of Contemporary Finance (Selected Problems) (pp. 145-158). Wroclaw, Poland: University of Wroclaw. URL: https://repozytorium.uni.wroc.pl/dlibra/publication/1 01511/edition/94285/content. Accessed on September 17, 2019.

Tanaka H. (2006), Carpathian Euroregion and crossborder governance. The Journal of Comparative Economic Studies, 2, 59-80. URL: http://www.ces.kier.kyoto-u.ac.jp/jces/o2_jces_2006/ 05_Tanaka.pdf_Accessed on September, 17, 2019.

UNEP (2011), EU strategy for the Danube Region: The Carpathian Region - a macro-region forming an 
integrated part of the Danube Region. Vienna, Austria: UNEP - Interim Secretariat of the Carpathian Convention. URL: https://ec.europa.eu/regional_policy /archive/consultation/danube/doc/contrib/eur_unep.p df. Accessed on September 17, 2019.

Yasinovska I., Smolinska S. (2018), Improvement of investment activity of enterprises. In: Improvement of Investment Activity of Enterprises: Challenges of Contemporary Finance (Selected Problems) (pp. 181192). Wroclaw, Poland: University of Wroclaw. URL: http://www.bibliotekacyfrowa.pl/ publication/101224. Accessed on September 17, 2019. 